\title{
Cholinesterase as inflammatory markers in a experimental infection by Trypanosoma evansi in rabbits
}

\author{
MÁRCIO M. COSTA ${ }^{1,2}$, ALEKSANDRO S. DA SILVA ${ }^{2}$, FRANCINE C. PAIM ${ }^{1}$, RAQUELI FRANÇA ${ }^{1}$, \\ GUILHERME L. DORNELLES ${ }^{1}$, GUSTAVO R. THOMÉ ${ }^{3}$, JONAS D.S. SERRES ${ }^{3}$, ROBERTA SCHMATZ ${ }^{3}$, \\ ROSÉLIA M. SPANEVELLO ${ }^{3}$, JAMILE F. GONÇALVES ${ }^{3}$, MARIA ROSA C. SCHETINGER ${ }^{3}$, \\ CINTHIA M.A. MAZZANTI ${ }^{1}$, SONIA T.A. LOPES ${ }^{1}$ and SILVIA G. MONTEIRO ${ }^{2}$ \\ ${ }^{1}$ Laboratório de Análises Clínicas Veterinária (LACVet), Universidade Federal de Santa Maria, \\ Av. Roraima, 1000, Cidade Universitária, Bairro Camobi, 97105-900 Santa Maria, RS, Brasil \\ ${ }^{2}$ Laboratório de Microbiologia e Parasitologia (LAPAVET), Universidade Federal de Santa Maria, \\ Av. Roraima, 1000, Cidade Universitária, Bairro Camobi, 97105-900 Santa Maria, RS, Brasil \\ ${ }^{3}$ Laboratório de Enzimologia Toxicológica - ENZITOX, Universidade Federal de Santa Maria, \\ Av. Roraima, 1000, Cidade Universitária, Bairro Camobi, 97105-900 Santa Maria, RS, Brasil
}

Manuscript received on June 13, 2011; accepted for publication on April 14, 2012

\begin{abstract}
The aim of this study is to evaluate the role of cholinesterases as an inflammatory marker in acute and chronic infection by Trypanosoma evansi in rabbits experimentally infected. Twelve adult female New Zealand rabbits were used and divided into two groups with 6 animals each: control group (rabbits 1-6) and infected group (rabbits 7-12). Infected group received intraperitoneally $0.5 \mathrm{~mL}$ of blood from a rat containing 108 parasites per animal. Blood samples used for cholinesterases evaluation were collected on days $0,2,7,12,27,42,57,87,102$ and 118 days post-inoculation (PI). Increased activity $(\mathrm{P}<0.05)$ of butyrylcholinesterase $(\mathrm{BChE})$ and acetylcholinesterase $(\mathrm{AChE})$ were observed in the blood on days 7 and 27 , respectively and no differences were observed in cholinesterase activity in other periods. No significant difference in AChE activity $(\mathrm{P}>0.05)$ was observed in the encephalic structures. The increased activities of $\mathrm{AChE}$ and $\mathrm{BChE}$ probably have a pro-inflammatory purpose, attempting to reduce the concentration of acetylcholine, a neurotransmitter which has an anti-inflammatory property. Therefore, cholinesterase may be inflammatory markers in infection with $T$. evansi in rabbits.
\end{abstract}

Key words: acetylcholinesterase, butyrylcholinesterase, inflammation, T. evansi.

\section{INTRODUCTION}

Cholinesterases are enzymes present in cholinergic and non-cholinergic tissues, as well as in plasma and other body fluids. This group of enzymes is divided into two distinct categories, according to

Correspondence to: Márcio Machado Costa

E-mail:marmcvet@yahoo.com.br their substrate-specific, behavior in the presence of excess substrate and susceptibility to inhibitors (Çokuğraş 2003). The acetylcholinesterase (AChE) is a specific cholinesterase, which hydrolyzes esters of mainly acetylcholine (ACh) and has high levels in nervous tissue and in erythrocytes (Soreq and Seidman 2001, Das 2007). Butyrylcholinesterase 
(BChE) is a non-specific cholinesterase, called pseudocholinesterase, which catalyzes the hydrolysis of other esters such as succinylcholine and butyrylcholine, as well as ACh (Çokuğraş 2003, Darvesh et al. 2003). The AChE mainly, but also the $\mathrm{BChE}$, have the function of hydrolyzing $\mathrm{ACh}$ linked to post-synaptic receptors to regulate the concentration of transmitter in the nerve synapse (Soreq and Seidman 2001).

The autonomic nervous system plays an important role in controlling the immune response, in terms of regular, partially, the release of proinflammatory cytokines, through the secretion of adrenaline and noradrenaline, and connection of these receptors $\alpha$ and $\beta$ androgenic in the immune cells (Pavlov and Tracey 2005). In contrast, the vagal efferent pathway plays an important role in modulating inflammation and was called cholinergic anti-inflammatory pathway (Borovikova et al. 2000, Pavlov and Tracey 2005).

The ACh, the principal neurotransmitter in vagal, has an important role in attenuating the release of pro-inflammatory cytokines such as tumor necrosis factor (TNF), interleukin-1 (IL-1), interleukin-6 (IL-6) and interleukin-18 (IL-18), activated macrophage previously by endotoxin, without affecting the production of interleukin-10 (IL-10), an anti-inflammatory cytokine (Pavlov and Tracey 2005). This inhibition is due to binding of ACh at $\alpha 7$ subunit-containing nicotinic acetylcholine receptor $(\alpha 7 \mathrm{nAChE})$ present on macrophages, being the dose-dependent inhibition (Ulloa 2005). Thus, given the important role of $\mathrm{ACh}$ in the suppression of inflammation, investigate of cholinesterases that regulate the concentration of $\mathrm{ACh}$ can be useful, even indirectly; the levels of ACh are measured.

The trypanosomosis are diseases that affect different species of animals such as camels, horses, cattle, goats, pigs, dogs, elephants, capybaras, coatis, tapirs, deer and wild rodents (Silva et al. 2002). Among these diseases, there is the "Surra" as it is called in India, which is caused by Trypanosoma evansi (T. evansi), a digenetic protozoan section salivate, which is mechanically transmitted by flies of the genus Tabanus and Stomoxis (Brun et al. 1998, Taylor and Authié 2004). In Brazil, trypanosomosis affects mainly horses, being called as "Mal das cadeiras" due to locomotor and neurological symptoms presented by infected animals (paralysis of hind limbs), resulting in incoordination (Herrera et al. 2004).

Among the affected animals, camels, horses, buffaloes and dogs have the most severe form of the disease, unlike of cattle and pigs which are moderately affected or asymptomatic (Taylor and Authié 2004). The acute phase of the disease mainly affects young animals and pregnant females (Tailor and Authié 2004) and progresses to death within weeks or months (Brun et al. 1998). On the other hand, the chronic stage is more frequent in endemic areas of disease (Taylor and Authié 2004) and affected animals can remain infected for many years (Brun et al. 1998). In equine trypanosomosis presents a chronic phase with clinical signs of progressive weight loss, fever, anemia, edema of limbs and lower portions of the body, incoordination and instability of the hind limbs and atrophy of muscle mass (Silva et al. 1995, Conrado et al. 2005, Rodrigues et al. 2005). In other animals such as rabbits, trypanosomiasis also has a chronic course, studying with anorexia, apathy, pale mucous membranes and edema of eyelids and ears. These animals show irregular peaks of parasitemia for long periods (Da Silva et al. 2009). Thus, these animals are good models for chronic infections due to low peak of parasitemia and long time of infection, as occurs in cases of natural infection.

Since these animals have low peak parasitemia, and both AChE and BChE to serve as possible markers of low-grade systemic inflammation in diseases (Das 2007), it is interesting to investigate in detail the inflammatory characteristics of cholinesterases in infection with $T$. evansi. Therefore, the objective of this study is to evaluate the role of cholinesterase as inflammatory markers 
in acute and chronic phase of T. evansi infection, using rabbits as an experimental model.

\section{MATERIALS AND METHODS}

\section{ANIMALS}

Twelve adult female rabbits New Zealand, weighing between 3.6 to $4.5 \mathrm{~kg}$ were used in this study. The animals were kept in individual cages with controlled temperature and humidity $\left(23^{\circ} \mathrm{C}\right.$ and $70 \%$ U.R.), fed with commercial ration and water ad libitum. All animals received a single dose $(5 \mathrm{mg} / \mathrm{kg}$, orally) of a commercial product containing pyrantel pamoate, praziquantel, and fenbendazole 30 days before beginning the experiment. Hematological (erythrogram, leukogram and platelet count) and biochemical (hepatic and renal function) examinations were performed twice with 15-day intervals. After 30 days (day 0 of the experiment), the evaluated patterns showed normal values (Campbell 2007).

The procedure was approved by the Animal Welfare Committee of the Universidade Federal de Santa Maria, number 23081.020268/200876 , in accordance to Brazilian laws and ethical principles published by the Colégio Brasileiro de Experimentação Animal.

\section{TRYPANOSOME INFECTION}

T. evansi was originally isolated from a naturally infected dog (Colpo et al. 2005). First, a rat was intraperitoneally infected with blood cryopreserved in liquid nitrogen containing $10^{6}$ parasites. This procedure was performed to obtain large amount parasites for posterior inoculation.

Rabbits were divided into two groups with 6 animals each, a control group (rabbits 1-6) and an infected group (rabbits 7-12). Infected group were intraperitoneally inoculated with $0.5 \mathrm{~mL}$ of rat blood containing $10^{8}$ trypanosomes (Day 1). Control group received physiological solution by the same route. The number of inoculated flagellates was estimated by Neubauer chamber (Wolkmer et al. 2007).
ESTIMATION OF PARASITEMIA

Parasitemia was estimated daily during 118 days of infection through microscopic examination of smears. Each slide was mounted with blood collected from the ear vein, stained by the panoptic method, and visualized at a magnification of $\times 1,000$.

\section{BLOOD SAMPLING AND ENCEPHALIC TISSUE}

The experimental period reached 118 days. Blood sampling for hematology and evaluation of cholinesterases were carried out on days $0,2,7,12$, 27, 42, 57, 87, 102 and 118 days post-inoculation (PI), by cardiac puncture using $5 \mathrm{~mL}$ disposable syringes and $25 \times 7$ needles, stored in tubes with anticoagulant. For this procedure all animals were anesthetized with ketamine $(1 \mathrm{mg} / \mathrm{Kg})$ and xylazine $(0.8 \mathrm{mg} / \mathrm{Kg})$, as recommended by the ethics committee. Blood with anticoagulant were diluted in a lytic buffer, proportion of 1:50 (v/v), to evaluate the activity of AChE. One $\mathrm{mL}$ of blood without anticoagulant was centrifuged for 10 minutes at $3,400 \mathrm{rpm}$, and serum separated and stored frozen at $-20^{\circ} \mathrm{C}$ for analysis of $\mathrm{BChE}$ activity.

For hematological evaluation $1 \mathrm{~mL}$ of blood with anticoagulant (EDTA 10\%) was collected by cardiac puncture on days $0,5,20,35,50,65,80,95$ and 118. At 118 days PI, euthanasia of all animals were performed with the same anesthetic protocol for sedation, however with doses tripled (ketamine: $30 \mathrm{mg} / \mathrm{Kg}$ and xylazine: $4 \mathrm{mg} / \mathrm{Kg}$ ), as recommended by Taborda et al. (2004). Encephalons were removed, followed by separation of structures such as cerebellum, cerebral cortex, striatum and hippocampus, with each structure individually weighed and stored in a buffer Tris- $\mathrm{HCl}(10 \mathrm{mmol}$, $\mathrm{pH}$ 7.2, $160 \mathrm{mmol}$ sucrose). Later, encephalic structures were homogenized with a sonicator, followed by centrifugation and separation of the supernatant and frozen $\left(-20^{\circ} \mathrm{C}\right)$, to posterior evaluation of cholinesterases. 
DETERMINATION OF ACHE ACTIVITY IN BLOOD AND

ENCEPHALON

The AChE enzyme assay in total blood was determined by the method of Ellman et al. (1961), modified by Worek et al. (1999). The specific activity of AChE in blood was calculated from the quotient between AChE activity and hemoglobin content, with results expressed in $\mathrm{mU} / \mathrm{L} \neg \mathrm{mol} \mathrm{Hb}$. The enzyme assay of AChE in encephalon was determined by a modification of the spectrophotometric method of Ellman et al. (1961) as described by Rocha et al. (1993). All readings were performed in triplicate and the enzyme activity was expressed in mumoles $\mathrm{AcSCh} / \mathrm{h} / \mathrm{mg}$ of protein.

\section{DETERMINATION OF BCHE ACTIVITY IN SERUM}

The methodology used to assess the AChE activity was also used for determination of BChE activity in serum, except for the acetylcholine substrate which was replaced by butyrylthiocholine. Results were expressed in $\mu$ moles $\mathrm{BcSCh} / \mathrm{h} / \mathrm{mg}$ of protein.

\section{DETERMINATION OF HEMATOLOGICAL PARAMETERS}

Hematologic parameters were evaluated merely to monitor the disease in rabbits infected with T. evansi. Hematocrit, total leukocytes and differential leukocyte were performed. The white blood cells counts were carried out in an automatic counter Mindray BC 2800 Vet $^{\circledR}$. Determination of hematocrit was obtained from microhematocrit centrifuge in rotation $19720 \mathrm{G}$, and the differential count was performed on blood smears, stained with Panoptic method ${ }^{\circledR}$, using light microscopy.

\section{STATISTICAL ANALYSIS}

By presenting normal distribution (Kolmogorov Smirnov), the data were subjected to $t$ test for independent samples. Data were considered significantly different with a probability $(\mathrm{P})$ less than 5\%.

\section{RESULTS}

\section{PARASITEMIA AND CLINICAL COURSE OF INFECTION}

Examination of the peripheral blood smears showed a prepatency period between 24 and 72 hours in the infected rabbits. Irregular waves of parasitemia, ranging from zero to one trypomastigote per microscopic field, were observed until 35 days PI. Parasites were no longer observed in blood smears from the $37^{\text {th }}$ day onwards (Figure 1).

Clinical signs as hyporexia, fever and weight loss $(8.7 \%)$ were observed during the first 30 days PI in all infected rabbits (acute phase and peak of parasitemia). Edema of the eyelids, ears and vulva was observed in all infected animals at determined periods of the experiment. This clinical signs disappeared in a few moments, reappearing after a period that varied among individuals. At days 60, 90 and 118 PI the infected rabbits increased its weights. Non-infected rabbits showed no clinical changes and increased its weights throughout the study.

\section{HEMATOCRIT}

Rabbits infected with $T$. evansi did not presente anemia. However, a significant reduction of hematocrit was observed $5(P<0.01)$ and $65(P<0.05)$ days PI, when compared to the control group. During the other days of evaluation this change was not observed (Figure 2A).

\section{TOTAL LEUKOCYTES AND LYMPHOCYTES}

Significant difference in total white cell count were not observed between the groups $(P>0.05)$. However, lymphocytes number were reduced in infected animals on days 20,65, 80 and 95 PI $(P<0.05)$ when compared to the non-infected (Figure 2B).

\section{ACTIVITY OF ACHE IN BLOOD AND ENCEPHALIC STRUCTURES}

An increase in AChE activity on day 27 PI (Figure 3A) was observed. During the other days 


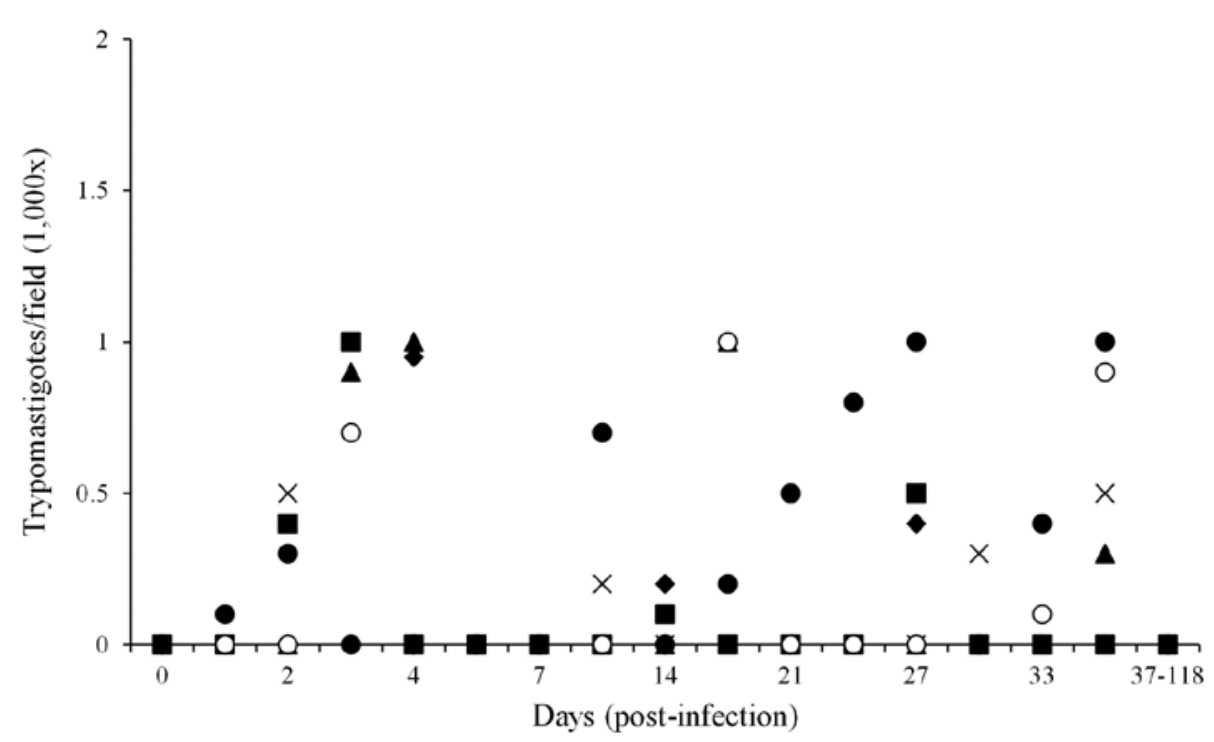

-Rabbit 7

Rabbit 8

$\Delta$ Rabbit 9

$\times$ Rabbit 10

ORabbit 11

-Rabbit 12

Figure 1 - Parasitemia of T. evansi in infected rabbits along the 118 days post-infection.

A)

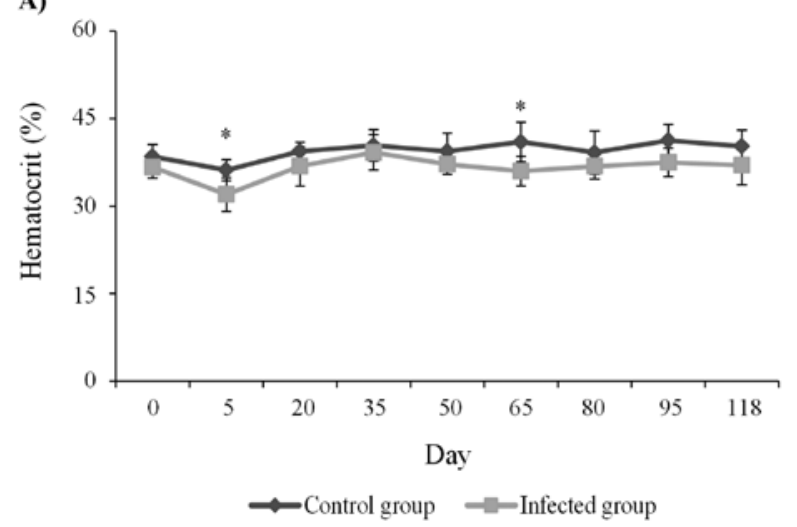

B)

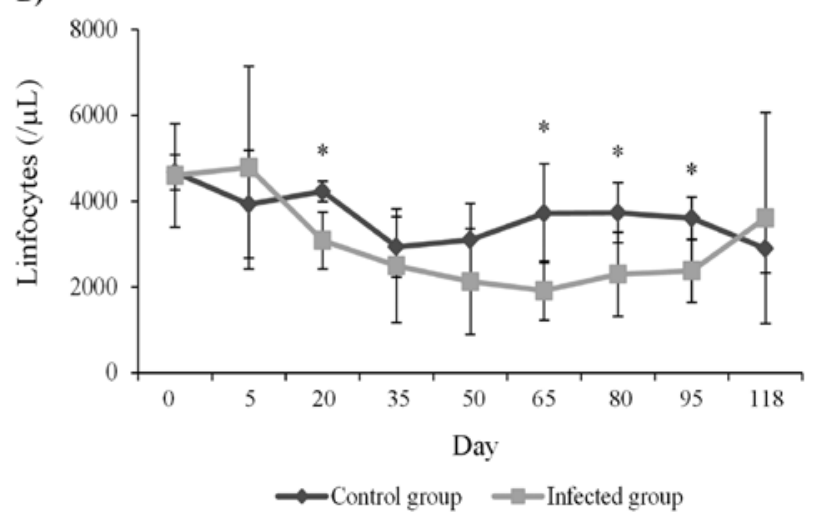

Figure 2 - Influences of the infection by T. evansi on hematological parameters of rabbits experimentally infected: A) hematocrit and B) lymphocytes. * indicates statistical difference between infected and control group (*Independent samples T test $P<0.05$ ).

significant differences in enzyme activity were not detected. No significant difference in AChE activity $(P>0.05)$ was observed in the brain structures, as shown in Figure 3C.

\section{ACTIVITY OF BCHE IN SERUM}

A significant increase $(P<0.05)$ on BChE activity was observed on day 7 PI (Figure 3B). During other days the enzyme activity did not show statistical difference when compared to the control group.

\section{DISCUSSION}

In animals infected, occurred a prepatent period shorter than that observed by Da Silva et al. (2008a), which used male rabbits, aged between two to six months. Also, irregular peaks of parasitemia were observed during the experiment, with T. evansi in the bloodstream until the $35^{\text {th }}$ day PI. In rabbits analyzed by Da Silva et al. (2008a), the parasitemia remained for 89 days, with total absence of trypomastigotes from that time on. These differences, into the same 

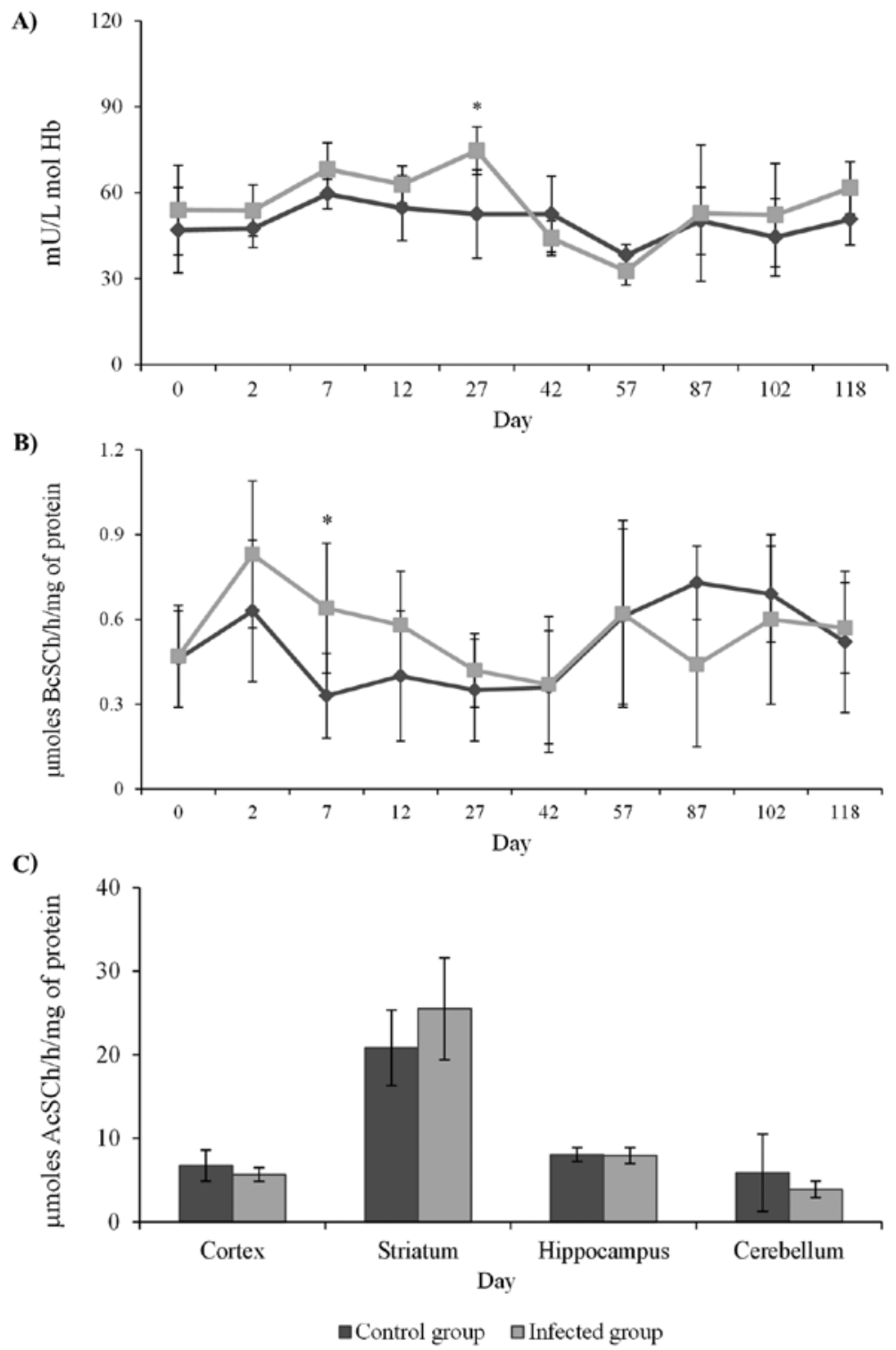

Figure 3 - A) Acetylcholinesterase activity in blood; B) butyrylcholinesterase activity in serum; and C) acetylcholinesterase in encephalic structures of rabbits experimentally infected with Trypanosoma evansi. * indicates statistical difference between infected and control group (*Independent samples T test $P<0.05$ ).

species, are mainly due to the mean age of animals, since animals tested by Da Silva et al. (2008a) were infected during its development phases, unlike the animals tested in this study, which were adult. A similar response to this study was found in coati experimentally infected with $T$. evansi that showed parasitemia until the first month PI, with subsequent decrease and absence of parasites in some periods (Herrera et al. 2001).
In this study, during the initial stage of the disease, clinical signs were observed such as appetite loss, fever and weight loss. These findings are similar to those found in cats (Da Silva et al. 2010), rabbits (Da Silva et al. 2009), dogs (Aquino et al. 1999, Colpo et al. 2005) and coatis (Herrera et al. 2001) experimentally or naturally infected with T. evansi. However, the presence of facial edema and vulva edema were the findings that persisted 
until euthanasia of animals, swinging during the experimental period. It was also observed in rabbits infected by Da Silva et al. (2009), however, after 90 days, the animals showed clinical improvement with disappearance of clinical signs, feature not observed in this study. Thus, animals in this study had a persistent and chronic infection, with absence of trypomastigotes in the bloodstream.

To the hematocrit, only at $5^{\text {th }}$ and $65^{\text {th }}$ days PI it was possible to observe a significant reduction. In the remaining days, the hematocrit of infected animals had small variations, but significant differences were not observed when compared to the control group, differing of results found by Da Silva et al. (2008b), which demonstrated a hematocrit reduction in rabbits experimentally infected with $T$. evansi, which returned to normal levels after 60 days PI. However, in a T. evansi outbreak in horses reported by Zanette et al. (2008), the animals did not show anemia, even with clinical signs of swinging gait and incoordination of the hind limbs, which agrees with the study in question, since the rabbits showed such clinical signs and absence of anemia.

Infection with $T$. evansi promoted increase in BChE activity only on the seventh day PI. These results are different from those found by Da Silva et al. (2010) and Wolkmer et al. (2010), as, in both studies, there was a reduction in $\mathrm{BChE}$ activity in cats and rats infected with $T$. evansi, respectively. Although in different stages of disease, both studies found similar results, with reduction of $\mathrm{BChE}$ assigned by Wolkmer et al. (2010) to liver damage, because the liver is the principal organ of synthesis of plasma $\mathrm{BChE}$ (Chatonnet and Lockridge 1989) or the assigned to inflammatory process. The period in which BChE activity increased is classified as acute infection by T. evansi, and it is characterized by peak parasitemia, fever, appetite loss. Within this period, the macrophage plays a crucial role in the production of an efficient immune response against African trypanosomes. This cell is responsible for the initial production of pro-inflammatory cytokines such as tumor necrosis factor (TNF) and nitric oxide (NO) (Stijlemans et al. 2007). Thus, BChE could be involved in activation of macrophages, as it has nicotinic receptors for acetylcholine. Acetylcholine when linked to these receptor, produces a dose-dependent inhibition in cytokine production (Ulloa 2005). Therefore, it is suggested that the increase in $\mathrm{BChE}$ is related to hydrolysis of acetylcholine by reducing its levels and preventing its suppressive action.

On the other hand, the increased activity of AChE in blood was only on the $27^{\text {th }}$ day PI, within the chronic phase of infection, which differs from other studies involving T. evansi. Wolkmer et al. (2010) found blood AChE activity reduced in rats infected with T. evansi on the $3^{\text {th }}$ and $5^{\text {th }}$ days PI. However, Da Silva et al. (2010) found a reduction in blood AChE activity of cats experimentally infected with T. evansi on days $28^{\text {th }}$ and $56^{\text {th }} \mathrm{PI}$, associated with a reduction in brain activity of AChE. The results in these two studies were directly associated with neurological signs presented in both species (rats and cats), which were not observed in this study, since the rabbits did not show neurological abnormalities such as incoordination of hind limbs, and limb muscle atrophy. The absence of neurological findings is confirmed, whereas there was no significant statistical difference between the encephalic structures analyzed in this study, when compared with the control group. In a recent study Da Silva et al. (2011a) observed increase of AChE activity in brains of rats infected with T. evansi, concomitantly with neurological signs, demonstrating that rabbits has a different response to infection with T. evansi.

Activity increased of AChE at this period may be related to a reduced number of lymphocytes in the 20th day PI, since acetylcholine acts directly on the regulation of immune activity. On lymphocytes surface, there are nicotinic and muscarinic receptors for acetylcholine, which regulates its cellular activity. Recent studies have demonstrated the presence of nicotinic receptors in lymphocytes from 
mice, rats, rabbits and humans. Nicotinic receptors, through the binding with acetylcholine, play the function of suppression of the immune response in T lymphocytes (Kawashima and Fujii 2003). Thus, the increase of AChE could reduce the ACh for nicotinic receptors, enhancing the immune activity of $\mathrm{T}$ lymphocytes, promoting a improved response for cytokine production and regulation of parasitemia. Its may compensate the reduction in the total number of lymphocytes. This hypothesis can be explained since from the 37th day the presence of parasite in the bloodstream was no longer observed. Besides, a recent study from our research group, reached a positive correlation between increased numbers of lymphocytes and activation of AChE in lymphocytes of rats infected with T. evansi (Da Silva et al. 2011b). In this study, the increase of cholinesterase activity was expected throughout the chronic phase of infection, but this enzymatic activation did not occur, despite the clinical signs presented. Possibly, due the control of parasitemia, mainly by $\operatorname{IgG}$ and $\operatorname{IgM}$, as described by Uche et al. (1992), there are no needs of a permanent cellular immune response, which could reduce the levels of $\mathrm{AChE}$ close to the normality.

Thus, it is concluded that cholinesterases may have pro-inflammatory actions during the infection by $T$. evansi in rabbits, regulating the concentrations of ACh, which is a potent anti-inflammatory mediator. These findings demonstrate the role of rabbits as tolerant to $T$. evansi, reinforcing the idea that this animal plays an important function as reservoirs of the parasite.

\section{ACKNOWLEDGMENTS}

The authors would like to thank Conselho Nacional de Desenvolvimento Científico e Tecnológico (CNPq) and "Universal - CNPq" for the financial support.

\section{RESUMO}

O objetivo do presente estudo é avaliar o papel das colinesterases como marcadores inflamatórios nas fases aguda e crônica da infecção por T. evansi em coelhos infectados experimentalmente. Foram utilizados 12 coelhos adultos, fêmeas, da raça Nova Zelândia, divididos em dois grupos: um grupo controle, com seis animais (coelhos 1-6), e um grupo infectado, com seis animais (coelhos 7-12). Os animais pertencentes ao grupo infectados receberam, pela via intraperitoneal, $0,5 \mathrm{~mL}$ de sangue de rato contendo $10^{8}$ tripanossomas por animal. Amostras do sangue utilizado para avaliação das colinesterases foram coletadas nos dias $0,2,7,12,27,42,57,87,102$ e 118 pós-inoculação (PI). Aumento $(\mathrm{P}<0,05)$ na atividade da butirilcolinesterase (BChE) e da acetilcolinesterase foi observado no sangue nos dias 7 e 27 (PI), respectivamente e não foram observadas diferenças na atividade da colinesterase em outros períodos. Nenhuma diferença significativa na atividade da $\mathrm{AChE}(\mathrm{P}>0,05)$ foi observada nas estruturas encefálicas. $\mathrm{O}$ aumento de atividade da $\mathrm{AChE}$ e $\mathrm{BChE}$ provavelmente tenha finalidade pró-inflamatória, a fim de reduzir as concentrações de acetilcolina, neurotransmissor que apresenta propriedade anti-inflamatória. Portanto, as colinesterases podem ser marcadores inflamatórios na infecção por T. evansi em coelhos.

Palavras-chave: acetilcolinesterase, butirilcolinesterase, inflamação, T. evansi.

\section{REFERENCES}

Aquino LP, Machado RZ, Alessi AC, Marques LC, De CAstro MB AND Malheiros EB. 1999. Clinical, parasitological and immunological aspects of experimental infection with Trypanosoma evansi in dogs. Mem Inst Oswaldo Cruz 94: 255-260.

BOROVIKOVA LV, IVANOVA S, ZHANG M, YANG $\mathrm{H}$, BOTCHKINA GI, WATKINS LR, WANG H, ABUMRAD N, EATON JW AND TRACEY KJ. 2000. Vagus nerve stimulation attenuates the systemic inflammatory response to endotoxin. Nature 405: 458-462.

BRUN R, HECKER H AND LUN ZR. 1998. Trypanosoma evansi and T. equiperdum: distribution, biology, treatment and phylogenetic relationship (a review). Vet Parasitol 79: 95-107.

CAMPBELL TW. 2007. Hematologia de mamíferos: Animais de laboratório e espécies variadas. In: Thrall MA, Baker DC, Campbell TW, Denicola D, Fettman MJ, Lassen ED, Rebar A and Weiser G. Hematologia e bioquímica clínica veterinária. Roca: São Paulo, p. 201-214.

CHATONNET A AND LOCKRIDGE O. 1989. Comparison of butyrylcholinesterase and acetylcholinesterase. Biochem J 260: 625-634. 
Colpo CB, Monteiro SG, Stainki DR, Colpo ET AND HENRIQUES GB. 2005. Infecção natural por Trypanosoma evansi em cães. Ciênc Rural 35: 717-719.

Conrado AC, Lopes STA, Oliveira LSS, Monteiro SG, VARGAS DLB AND BUENO A. 2005. Infecção natural por Trypanosoma evansi em cavalos na região central do Rio Grande do Sul. Ciênc Rural 35: 928-931.

ÇOKUĞRAŞ AN. 2003. Butyrylcholinesterase: structure and physiological importance. Turk J Biochem 28: 54-61.

Da Silva AS, Costa MM, Doyle RL, Lopes STA AND MONTEIRO SG. 2008a. Infecção experimental por Trypanosoma evansi em coelhos. Ciênc Anim Bras 9: 519-523.

Da Silva AS, Costa MM, Lopes STA And Monteiro SG. 2008b. Alterações hematológicas em coelhos infectados experimentalmente pelo Trypanosoma evansi. Ciênc Rural 38: 538-542.

DA SILVA AS ET AL. 2011a. Acetylcholinesterase activity and lipid peroxidation in the brain and spinal cord of rats infected with Trypanosoma evansi. Vet Parasitol 175: 237-244.

DA SILVA AS ET AL. 2011b. Trypanosoma evansi: immune response and acetylcholinesterase activity in lymphocytes from infected rats. Exp Parasitol 127: 475-480.

Da Silva AS, Pereira PL AND Monteiro SG. 2009. Achados patológicos, sinais clínicos e ganho de peso de coelhos infectados experimentalmente por Trypanosoma evansi. Semina Ciênc Agrar 30: 93-98.

Da Silva AS, Spanevello R, Stefanello N, Wolkmer P, COSTA MM, ZANETTE RA, LOPES ST, SANTURIO JM, SCHETINGER MR AND MONTEIRO SG. 2010. Influence of Trypanosoma evansi in blood, plasma, and brain cholinesterase of experimentally infected cats. Res Vet Sci 88: 281-284.

DARVESh S, Hopkins DA AND GeUla C. 2003. Neurobiology of butyrylcholinesterase. Nat Rev Neurosci 4: 131-138.

DAS UN. 2007. Acetilcholinesterase and butyrylcholinesterase as possible markers of low-grade systemic inflammation. Med Sci Monit 13: 214-221.

Ellman GL, Coutney KO, ANDres V and Featherstone RM. 1961. A new and rapid colorimetric determination of acetylcholinesterase activity. Biochem Pharmacol 7: 88-95.

Herrera HM, Aquino LP, MENEZES RF, MARques LC, Moraes MA, Werther K AND MACHADO RZ. 2001. Trypanosoma evansi experimental infection in the South American coati (Nasua nasua): clinical, parasitological and humoral immune response. Vet Parasitol 102: 209-216.

Herrera HM, Dávila AM, Norek A, Abreu UG, Souza SS, D'ANDREA PS AND JANSEN AM. 2004. Enzootiology of Tryapanosoma evansi in pantanal, Brasil. Vet Parasitol 125: $263-275$.

KAWASHIMA K AND FUJII T. 2003. The lymphocytic cholinergic system and is contribution to the regulation of immune activity. Life Sci 74: 675-696.
PAVlOV VA AND TRACEY KJ. 2005. The cholinergic antiinflammtory pathway. Brain Behav Immu 19: 493-499.

Rocha JBT, Emanuelli T AND Pereira ME. 1993. Effects of early undernutrition on kinetic parameters of brain acetylcholinesterase from adult rats. Acta Neurobiol Exp (Wars) 53: 431-437.

Rodrigues A, FIGHERA RA, SOUZA TM, SCHILD AN, SoAres MP, Milano J AND Barros CSL. 2005. Surto de tripanossomíase por Trypanosoma evansi em equinos no Rio Grande do Sul: aspectos epidemiológicos, clínicos, hematológicos e parasitológicos. Pesq Vet Bras 25: 239-249.

Silva RA, Arosemena NA, Herrera HM, SAHib CA AND FERREIRA MS. 1995. Outbreak of trypanosomosis due to Trypanosoma evansi in horses of Pantanal matogrossense, Brazil. Vet Parasitol 60: 167-171.

SILVA RAMS, SEIDL A, RAMIREZ L AND DÁVILA AMR. 2002. Trypanosoma evansi e Trypanosoma vivax - biologia, diagnóstico e controle. Corumba: Embrapa Pantanal, 141 p.

SOREQ H AND SEIDMAN S. 2001. Acetylcholinesterase - new roles for an old actor. Nat Rev Neurosci 2: 294-302.

StiJlemans B, Guilliams M, Raes G, Beschin A, Magez S AND DE BAETSELIER P. 2007. African trypanosomosis: from immune escape and immunopathology to immune intervention. Vet Parasitol 148: 3-13.

TABorda C, Mehnert DU And Silva CA. 2004. Manual de Normas Técnicas: biotério de experimentação animal do Departamento de Microbiologia - Instituto de Ciências Biomédicas - USP, $24 \mathrm{p}$.

TAYLOR K AND AUTHIÉ EML. 2004. Pathogenesis of animal trypanosomiasis. In: Maudlin I, Holmes PH and Miles MA. The Trypanosomiases. London: CABI publishing, p. 331-354.

UChe UE, Jones TW AND BoID R. 1992. Antibody patterns in rabbits showing different levels of susceptibility to an experimental Trypanosoma evansi infection. Acta Trop 52: $139-147$.

UlLOA L. 2005. The vagus nerve and the nicotinic antiinflammatory pathway. Nat Rev Drug Discov 4: 673-684.

Wolkmer P, Lopes ST, Franciscato C, DA Silva AS, Traesel CK, Siqueira lC, Pereira ME, Monteiro SG AND MAZZANTI CM. 2010. Trypanosoma evansi: cholinesterase activity in acutely infected Wistar rats. Exp Parasitol 125: 251-255.

WolKMER P, Silva AS, CARnElutti JF, COSTA MM, TrAesel C, Lopes STA AND Monteiro SG. 2007. Resposta eritropoética de ratos em diferentes de graus de parasitemia por Trypanosoma evansi. Ciênc Rural 37: 1682-1687.

Worek F, Mast U, Kiderlen D, Diepold C AND Eyer P. 1999. Improved determination of acetylcholinestrase activity in human whole blood. Clin Chim Acta 288: 73-90.

Zanette RA, DA Silva AS, Costa MM, Monteiro, SG, SANTURIO JM AND LOPES STA. 2008. Ocorrência de Trypanosoma evansi em equinos no município de Cruz Alta, RS, Brasil. Ciênc Rural 38: 1468-1471. 